\title{
Blood group antigens in the normal and neoplastic bladder epithelium
}

\author{
SUSAN J THORPE, ${ }^{*}$ P ABEL,$\dagger$ G SLAVIN, ${ }^{*} \ddagger$ TEN FEIZI* \\ From the *Clinical Research Centre, Watford Road, Harrow, Middlesex HA1 3UJ, and the †Hammersmith \\ Hospital, Du Cane Road, London W12 OHS
}

SUMMARY The indirect immunofluorescence technique was used to study the expression of the blood group $\mathrm{A}$ and $\mathrm{H}$ antigens in fresh-frozen and formalin-fixed paraffin-embedded sections of the bladder mucosa of 21 patients with non-neoplastic diseases of the bladder. Reliable assessment of these antigens could only be made using cryostat sections of fresh-frozen tissues. Also included in this study were tumour tissues of 5 patients with bladder cancer. The blood group A antigen was totally deleted in cryostat sections of the tumour of one patient with aggressive carcinoma and the appropriate antigens were diminished or focally deleted in the four patients with tumours that were non-invasive during one to three years of follow-up.

It is concluded that sections of fresh-frozen tissues or sections processed in the absence of glycolipid-extracting solvents should be used for visualising the expression of blood group antigens in bladder tissues and assessing their value as prognosticators of the malignant potential of bladder tumours.

The blood group antigens, $\mathrm{A}, \mathrm{B}$ and $\mathrm{H}$ which are normally present on epithelial tissues ${ }^{1}$ have been reported as absent or reduced in a number of epithelial carcinomas (see reviews). ${ }^{2-4}$ Tumours of the transitional epithelium of the bladder often recur and may eventually invade or metastasise. ${ }^{5}$ The problem in clinical treatment is distinguishing those patients who will follow a benign clinical course from those who will eventually suffer from invasive disease and thus require more radical treatment before invasion and metastasis occurs. Several groups of workers have therefore examined the possibility that loss of the genetically predicted blood group antigens precedes the development of recurrent, invasive or metastatic cancer. Using paraffin-embedded sections and the Red Cell Adherence (RCA) test ${ }^{6}$ to detect the blood group antigens, a number of retrospective studies have suggested that these antigens are often absent or reduced in high grade tumours with poor prognosis and that preservation of the antigens in the initial tumour is associated with a good prognosis (see reviews). ${ }^{48}$ However, a significant number of patients whose initial tumours were

$\ddagger$ Professor Slavin’s present address: Department of Histopathology, St Bartholomew's Hospital, London EC1A 7BE.

Accepted for publication 28 March 1983 reported as blood group antigen negative failed to develop an invasive tumour. In contrast, other investigators using the RCA test on suspensions of unfixed tumour cells ${ }^{9}$ and formalin-fixed frozen sections ${ }^{10}$ found no clear correlation between antigen expression and degree of tumour malignancy. It is possible that these conflicting results may, at least in part, be explained by differences in methodology or interpretation, or both. Paraffin processing itself may result in at least partial antigen removal due to the action of organic solvents used to dehydrate the tissues prior to paraffin-embedding, ${ }^{11}{ }^{12}$ while the RCA test requires technical expertise, is difficult to interpret and standardise and does not allow cytological localisation of the antigen. ${ }^{13-16}$ Several groups have also reported that this method is unreliable for detection of $\mathrm{H}$ antigen and may give rise to a false impression of antigen deletion in group $\mathrm{O}$ tumours. ${ }^{15-19}$ Although some of the technical problems have been overcome using immunoperoxidase $^{1517}$ or immunofluorescence ${ }^{16}$ methods, it is clearly necessary to improve further and standardise current methodology before drawing any conclusions about the significance of antigen loss in bladder tumours. In this study we have used immunofluorescence microscopy to establish the cytological localisation and distribution of the $\mathrm{A}$ and $\mathrm{H}$ blood group antigens in fresh-frozen and paraffin-embedded 
tissues from patients of known blood group and secretor status without bladder cancer. Also included are observations on the blood group antigens in the tumours of five patients with bladder cancer.

\section{Material and methods}

\section{BLADDER TISSUES}

Biopsies* of bladder epithelium were obtained from 21 patients (all men aged 54 to $78 \mathrm{yr}$ ) undergoing cystoscopy for benign conditions such as prostatism or urinary tract infection and from five patients (Table 1) with transitional cell carcinoma undergoing diagnostic (cases Lym, Ste, Pal, Par) or follow-up (case Bon) cystoscopy. The biopsies were taken from the posterior wall of the bladder from patients with non-neoplastic conditions, and from tumour tissues and adjacent non-involved mucosae from the cancer patients using a Stortz resectoscope. The tissues were "snap-frozen" in isopentane cooled with liquid nitrogen, and/or fixed in neutral formol saline (4\% (wt/vol) formaldehyde in isotonic saline) for routine paraffin

*The samples were obtained with informed consent and with the approval of the ethical committees of Northwick Park Hospital, the Clinical Research Centre, and Musgrove Park Hospital.
Table 1 Histological assessment of bladder biopsy and clinical course in five patients with transitional cell carcinoma of the bladder

\begin{tabular}{|c|c|c|c|}
\hline $\begin{array}{l}\text { Case } \\
\text { (sex) }\end{array}$ & $\begin{array}{l}\text { Age } \\
(y r)\end{array}$ & $\begin{array}{l}\text { Histology* (Grade, } \\
\text { clinical stage) }\end{array}$ & Clinical course \\
\hline $\operatorname{Lym}(\mathrm{M})$ & 89 & $\begin{array}{l}\text { Transitional cell carci- } \\
\text { noma, poorly differen- } \\
\text { tiated, with invasion } \\
\text { of nerve and muscle. } \\
\text { (grade } 3, T 3 \text { ) }\end{array}$ & $\begin{array}{l}\text { Rapidly progressive } \\
\text { tumour, died } 10 \mathrm{wk} \\
\text { after onset of symptoms }\end{array}$ \\
\hline Ste (M) & 78 & $\begin{array}{l}\text { Papillary transitional } \\
\text { cell carcinoma of aver- } \\
\text { age grade malignancy } \\
\text { (grade } 2, T 2 \text { ) }\end{array}$ & No recurrence after $1 \mathrm{yr}$ \\
\hline Bon (M) & 71 & $\begin{array}{l}\text { Papillary transitional } \\
\text { cell carcinoma } \\
\text { (grade } 2, T 1 \text { ) }\end{array}$ & $\begin{array}{l}\text { Superficial recurrences } \\
\text { (T1) at each of } 5 \text { follow- } \\
\text { up cystoscopies over } 3 \mathrm{yr}\end{array}$ \\
\hline $\operatorname{Par}(F)$ & 71 & $\begin{array}{l}\text { Transitional cell carci- } \\
\text { noma of average grade } \\
\text { malignancy } \\
\text { (grade } 2, \mathrm{~T} 2 \text { ) }\end{array}$ & $\begin{array}{l}\text { Superficial recurrences } \\
\text { (T1) over } 15 \text { months }\end{array}$ \\
\hline Pal (M) & 80 & $\begin{array}{l}\text { Papillary transitional } \\
\text { cell carcinoma } \\
\text { (grade } 2, \mathrm{~T} 2 \text { ) }\end{array}$ & $\begin{array}{l}\text { Superficial recurrences } \\
\text { at each of } 5 \text { follow-up } \\
\text { cystoscopies over } 1 \mathrm{yr}\end{array}$ \\
\hline
\end{tabular}

*The descriptions apply to the bladder samples examined by immunofluorescence. These were taken at initial cystoscopy except with case Bon whose sample was taken from the first recurrent tumour 2 yr after the initial, stage $\mathrm{T} 2$ lesion was resected.

embedding. Both frozen and paraffin-embedded tissues were studied in 17 samples, frozen tissues only in eight samples, and paraffin-embedded tissues only in five samples (as described in Tables 2-4).

Table 2 Immunofluorescence staining of the blood group $H$ and $A$ antigens in non-neoplastic bladder epithelium of group $O$ and $A$ persons respectively

\begin{tabular}{|c|c|c|c|c|c|c|c|c|c|c|c|c|c|c|}
\hline \multirow[t]{4}{*}{ Case } & \multirow{4}{*}{$\begin{array}{l}\text { Blood } \\
\text { group }\end{array}$} & \multicolumn{13}{|c|}{ Immunofluorescence } \\
\hline & & \multirow{2}{*}{\multicolumn{2}{|c|}{ Intensity* }} & \multicolumn{6}{|c|}{ Regional variation } & \multicolumn{5}{|c|}{ Distribution } \\
\hline & & & & \multicolumn{2}{|c|}{ None } & \multicolumn{2}{|c|}{$\begin{array}{l}\text { Area to } \\
\text { area }\end{array}$} & \multicolumn{2}{|c|}{$\begin{array}{l}\text { Cell to } \\
\text { cell }\end{array}$} & \multicolumn{2}{|c|}{$\begin{array}{l}\text { Predominantly } \\
\text { pericellular }\end{array}$} & \multicolumn{2}{|c|}{$\begin{array}{l}\text { Cytoplasmic } \\
\text { and pericellular }\end{array}$} & Nuclear \\
\hline & & $F+$ & $P+$ & $F$ & $P$ & $\boldsymbol{F}$ & $\boldsymbol{P}$ & $F$ & $\boldsymbol{P}$ & $F$ & $\boldsymbol{P}$ & $F$ & $\boldsymbol{P}$ & $F$ \\
\hline
\end{tabular}

* Fluorescence intensity was arbitarily graded from 0 to 4; figures in brackets denote fluorescence restricted to small areas only. $t F=$ fresh frozen sections; $P=$ formalin-fixed paraffin embedded sections; $(S)=$ secretor; $(N S)=$ non-secretor; $n a=$ not available; $p n=$ perinuclear accentuition. "Non-neoplastic mucosae of patients with bladder cancer. $¥+$ indicates presence of regional variation in intensity and distribution of fluorescence throughout the epithelium or in limited areas $(+)$ of the epithelium. 
Table 3 Immunofluorescence staining of the blood group $H$ antigen in non-neoplastic bladder epithelium of blood graup $A$ and $B$ cases

\begin{tabular}{|c|c|c|c|c|c|c|c|c|c|c|c|c|c|c|c|}
\hline \multirow[t]{4}{*}{ Case } & \multirow{4}{*}{$\begin{array}{l}\text { Blood } \\
\text { group }\end{array}$} & \multicolumn{14}{|c|}{ Immunofluorescence* } \\
\hline & & \multirow{2}{*}{\multicolumn{2}{|c|}{ Intensity }} & \multicolumn{6}{|c|}{ Regional variation } & \multicolumn{6}{|c|}{ Distribution } \\
\hline & & & & \multicolumn{2}{|c|}{ None } & \multicolumn{2}{|c|}{$\begin{array}{l}\text { Area to } \\
\text { area }\end{array}$} & \multicolumn{2}{|c|}{$\begin{array}{l}\text { Cell to } \\
\text { cell }\end{array}$} & \multicolumn{2}{|c|}{$\begin{array}{l}\text { Predominantly } \\
\text { pericellular }\end{array}$} & \multicolumn{2}{|c|}{$\begin{array}{l}\text { Cytoplasmic } \\
\text { and pericellular }\end{array}$} & \multicolumn{2}{|c|}{ Nuclear } \\
\hline & & $F$ & $\boldsymbol{P}$ & $F$ & $\boldsymbol{P}$ & $F$ & $P$ & $F$ & $P$ & $\boldsymbol{F}$ & $P$ & $F$ & $P$ & $F$ & $P$ \\
\hline $\begin{array}{l}\text { Cho } \\
\text { Dra } \\
\text { Hop } \\
\text { Pip } \\
\text { Woo } \\
\text { Wal } \\
\text { Hun } \\
\text { Bra } \\
\text { Qui } \\
\text { Woo } \\
\text { Har } \\
\text { Fin } \\
\text { Dur }\end{array}$ & $\begin{array}{l}\text { A (S) } \\
\text { A (S) } \\
\text { A (S) } \\
\text { A (S) } \\
\text { A (S) } \\
\text { A (S) } \\
\text { A (?) } \\
\text { A (NS) } \\
\text { A (NS) } \\
\text { A (NS) } \\
\text { B (S) } \\
\text { B (NS) } \\
\text { B (NS) }\end{array}$ & $\begin{array}{l}3 / 4 \\
2 / 3 \\
1 / 2 \\
2 / 3 \\
2 / 3 \\
2 / 3 \\
2 / 3 \\
\text { na } \\
\text { na } \\
3 \\
4 \\
3 / 4 \\
3 / 4\end{array}$ & $\begin{array}{l}\text { na } \\
\text { na } \\
\text { na } \\
0 /(3) \\
0 /(3) \\
0 /(3) \\
0 /(3) \\
0 \\
0 \\
0 \\
0 /(3) \\
0 /(1) \\
0\end{array}$ & $\begin{array}{l}+ \\
+ \\
+ \\
+ \\
+ \\
+ \\
+\end{array}$ & & & $\begin{array}{l}+ \\
+ \\
+ \\
+\end{array}$ & & $\begin{array}{l}+ \\
+ \\
+ \\
+\end{array}$ & & + & $\begin{array}{l}+ \\
+ \\
+ \\
+ \\
+ \\
+ \\
+\end{array}$ & $\begin{array}{l}+ \\
+ \\
+\end{array}$ & $\begin{array}{l}+ \text { pn } \\
+ \text { pn } \\
+ \\
+ \text { pn }\end{array}$ & \\
\hline
\end{tabular}

*Symbols and abbreviations as in Table 2 .

Histological assessment and tumour grading according to Mostofi ${ }^{20}$ were made on sections stained with haematoxylin and eosin. The clinical staging of the tumours was made according to the International Union Against Cancer. ${ }^{21}$

\section{IMMUNOFLUORESCENCE}

Details of the anti-blood group sera and the immunofluorescence procedure have been described previously. ${ }^{22}$ In brief, cryostat sections were cut at 6 $\mu \mathrm{m}$, air-dried and fixed for $15 \mathrm{~min}$ in acetone at $4^{\circ} \mathrm{C}$. Formalin-fixed paraffin-embedded sections $(4 \mu \mathrm{m})$ were dewaxed in xylene and cleared through alcohol. The sections were incubated at $4^{\circ} \mathrm{C}$ with rabbit antisera to blood group $\mathrm{A}$ or $\mathrm{H}$ antigens (batches 778 and 130 respectively; kindly provided by $\mathrm{Dr} \mathrm{W}$ Watkins) followed by fluorescein conjugated goat anti-rabbit IgG (Miles Laboratories, Slough, England). Nonimmune rabbit serum was used instead of the anti- blood group sera as a negative control. The sections were then fixed in $1 \%$ (wt/vol) paraformaldehyde and mounted in buffered glycerol (PBS: glycerol, 1:9 $\mathrm{vol} / \mathrm{vol})$ containing $p$-phenylenediamine. ${ }^{23}$ Some tumour sections were counterstained with haematoxylin after immunofluorescence labelling to improve phase contrast photography. Sections were viewed with a Zeiss epifluorescence microscope without prior knowledge of the patients' blood group and clinical assessment. The intensity of immunofluorescence above control was graded from weak (1) to strong (4).

Fluorescence and phase contrast photomicrographs were taken using Ilford HP5 and Pan F films respectively.

DETERMINATION OF 'SECRETOR' STATUS

Saliva samples were tested for the presence of blood

Table 4 Immunofluorescence staining of the blood group $H$ and $A$ antigens in bladder tumours of persons of blood groups $O$ and $A$ respectively and immunofluorescence of $H$ antigen in the tumour of a group $A$ person

\begin{tabular}{|c|c|c|c|c|c|c|c|c|c|c|c|c|c|}
\hline \multirow[t]{4}{*}{ Case } & \multirow{4}{*}{$\begin{array}{l}\text { Blood } \\
\text { group }\end{array}$} & \multicolumn{12}{|c|}{ Immunofluorescence } \\
\hline & & \multirow{2}{*}{\multicolumn{2}{|c|}{ Intensity }} & \multicolumn{6}{|c|}{ Regional variation } & \multicolumn{4}{|c|}{ Distribution } \\
\hline & & & & \multicolumn{2}{|c|}{ None } & \multicolumn{2}{|c|}{$\begin{array}{l}\text { Area to } \\
\text { area }\end{array}$} & \multicolumn{2}{|c|}{$\begin{array}{l}\text { Cell to } \\
\text { cell }\end{array}$} & \multicolumn{2}{|c|}{$\begin{array}{l}\text { Predominantly } \\
\text { pericellular }\end{array}$} & \multicolumn{2}{|c|}{$\begin{array}{l}\text { Cytoplasmic } \\
\text { and pericellular }\end{array}$} \\
\hline & & $\bar{F}$ & $P$ & $F$ & $P$ & $F$ & $P$ & $F$ & $P$ & $F$ & $P$ & $F$ & $P$ \\
\hline $\begin{array}{l}\text { Bon } \\
\text { Pal } \\
\text { Par } \\
\text { Ste } \\
\text { Lym }\end{array}$ & 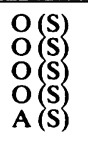 & $\begin{array}{l}1 / 3 \\
0 / 3 \\
1 \\
1 /(3) \\
0 \\
\text { Immunofl }\end{array}$ & $\begin{array}{l}0 /(4) \\
0 /(4) \\
\text { na } \\
\text { na } \\
\text { na } \\
\text { lorescer }\end{array}$ & + & Ing $\mathrm{C}$ & $\begin{array}{l}+ \\
+ \\
+\end{array}$ & + & $\begin{array}{l}+ \\
+ \\
+ \\
\text { der } c\end{array}$ & $\begin{array}{l}+ \\
+\end{array}$ & + & $\begin{array}{l}+ \\
+\end{array}$ & $\begin{array}{l}(+) \\
(+) \\
+ \\
+ \\
\text { A }\end{array}$ & $(+)$ \\
\hline Lym & $A(S)$ & $0 /(3)$ & na & & & + & & + & & & & + & \\
\hline
\end{tabular}

Symbols and abbreviations as in Table 2 . 
group $\mathrm{A}, \mathrm{B}$ and $\mathrm{H}$ substances by haemagglutination inhibition assays as described previously. ${ }^{24}$

\section{Results}

NON-NEOPLASTIC BLADDER EPITHELIUM

The distribution and intensity of immunofluorescence of the blood group $\mathrm{A}$ and $\mathrm{H}$ antigens in the bladder epithelia of patients with non-neoplastic conditions and in the uninvolved mucosae of patients with bladder cancer were similar (Tables 2 and 3 ).

\section{Cryostat sections}

Anti-A immunofluorescence was detected in the epithelium and the intimal cells in patients with erythro- cytes of blood group A, but not in those of blood groups $\mathbf{O}$ or $\mathbf{B}$. The pattern of immunofluorescence was predominantly cytoplasmic (with nuclei appearing unstained), and uniform in intensity throughout the epithelium in each sample (Figs. 1A, C and E).

Anti-H immunofluorescence was detected in the epithelium of blood group $\mathrm{O}$ as well as $\mathrm{A}$ and $\mathrm{B}$ persons (Figs. 2A, D and F and $3 A, C$ and F). The pattern of fluorescence was similar to that seen with anti-A, but fluorescence was also observed in the nuclei of epithelial cells with or without perinuclear accentuation and in connective tissue cells underlying the epithelium.

\section{Formalin-fixed paraffin-embedded sections}

In contrast to the cryostat sections, the paraffin-

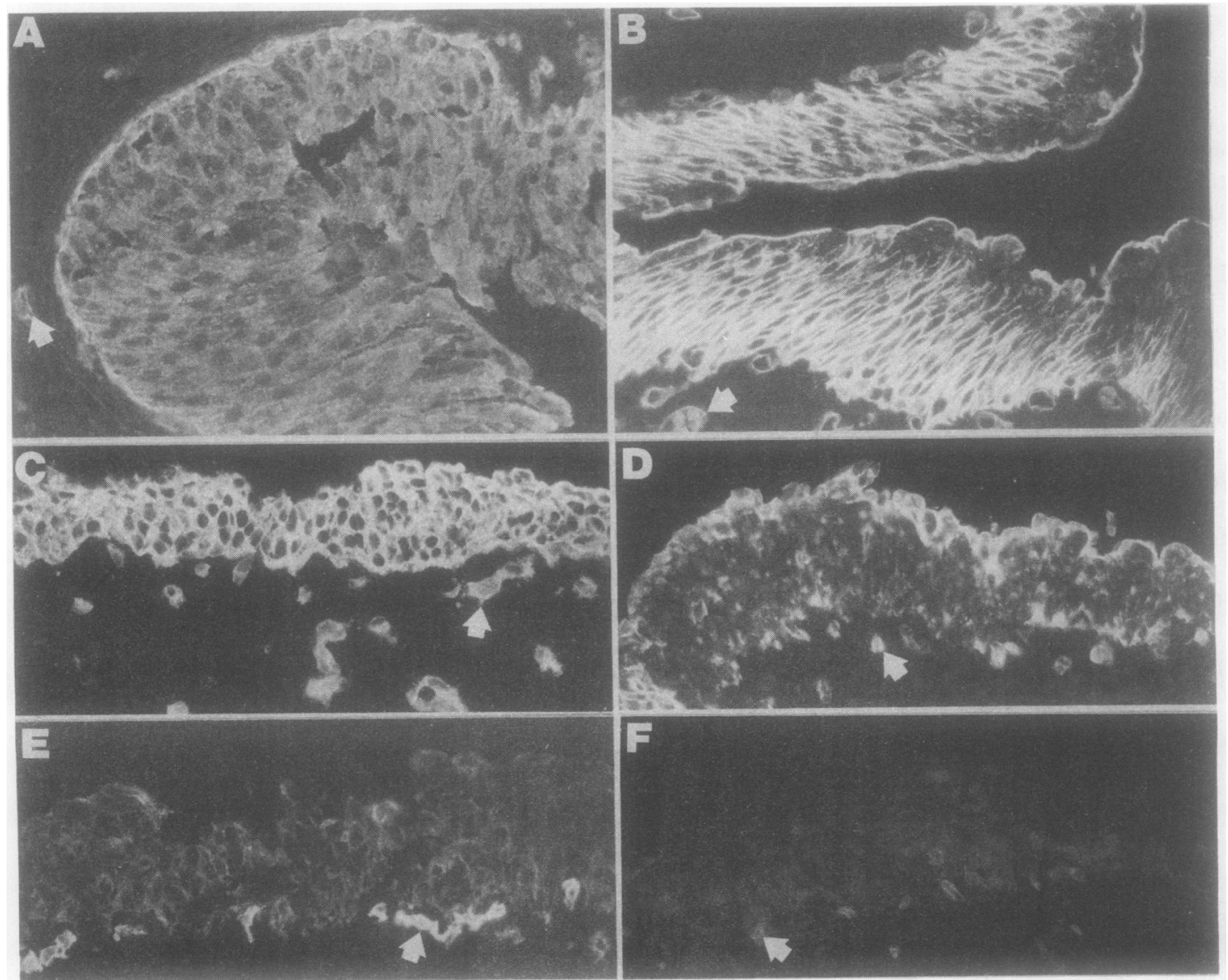

Fig. 1 Immunofluorescence staining of the blood group $A$ antigen in cryostat sections $(A, C, E)$ and paraffin sections $(B, D$, $F)$ of non-neoplastic bladder epithelium from persons of blood group $A .(A, B)$ and $(C, D)$ are from cases Wal and Pip (secretors) and $(E, F)$ from case Moo (non-secretor). Immunofuorescence staining is also seen in endothelial cells (arrowed) below the epithelium. Magnification $\times 225$. 
embedded sections showed variable patterns of anti$\mathrm{A}$ and $\mathrm{H}$ immunofluorescence (Figs. 1B, D and F, 2B, C, E and G, and $3 B, D, E$ and G). The fluorescence appeared predominantly pericellular rather than cytoplasmic, and varied in intensity from cell to cell. In most cases, the fluorescence was substantially reduced compared to the cryostat sections, and in some regions completely abolished; this was more pronounced for $\mathrm{H}$ antigen immunofluorescence which was often confined to only occasional epithelial cells, or to their luminal aspects.

\section{Effect of secretor status}

In cryostat sections, blood group antigen immunofluorescence was seen in non-secretors as well as secretors (Figs. 1E, $2 \mathrm{~F}$ and $3 \mathrm{~F}$ ). The $\mathrm{A}$ and $\mathrm{H}$ immuno- fluorescence in the three non-secretors of blood groups $\mathrm{A}$ and $\mathrm{O}$ was among the weakest in the series; however, two of the blood group $\mathrm{O}$ secretors also showed weak immunofluorescence of the $\mathrm{H}$ antigen (Tables 2 and 3 ).

In the paraffin sections of non-secretors the residual fluorescence of the $A$ and $H$ antigens in group $A$ and $O$ persons respectively and $H$ antigen in group $A$ and $B$ persons was substantially less than the paraffin sections of secretors (Figs $1 F, 2 G$ and $3 G$ ).

\section{BLADDER CARCINOMA}

The immunofluorescence of the blood group $A$ and $H$ antigens in the five bladder tumours included in this study are summarised in Table 4 . Three patterns of immunofluorescence were noted.

(a) Complete deletion of antigen. This occurred in
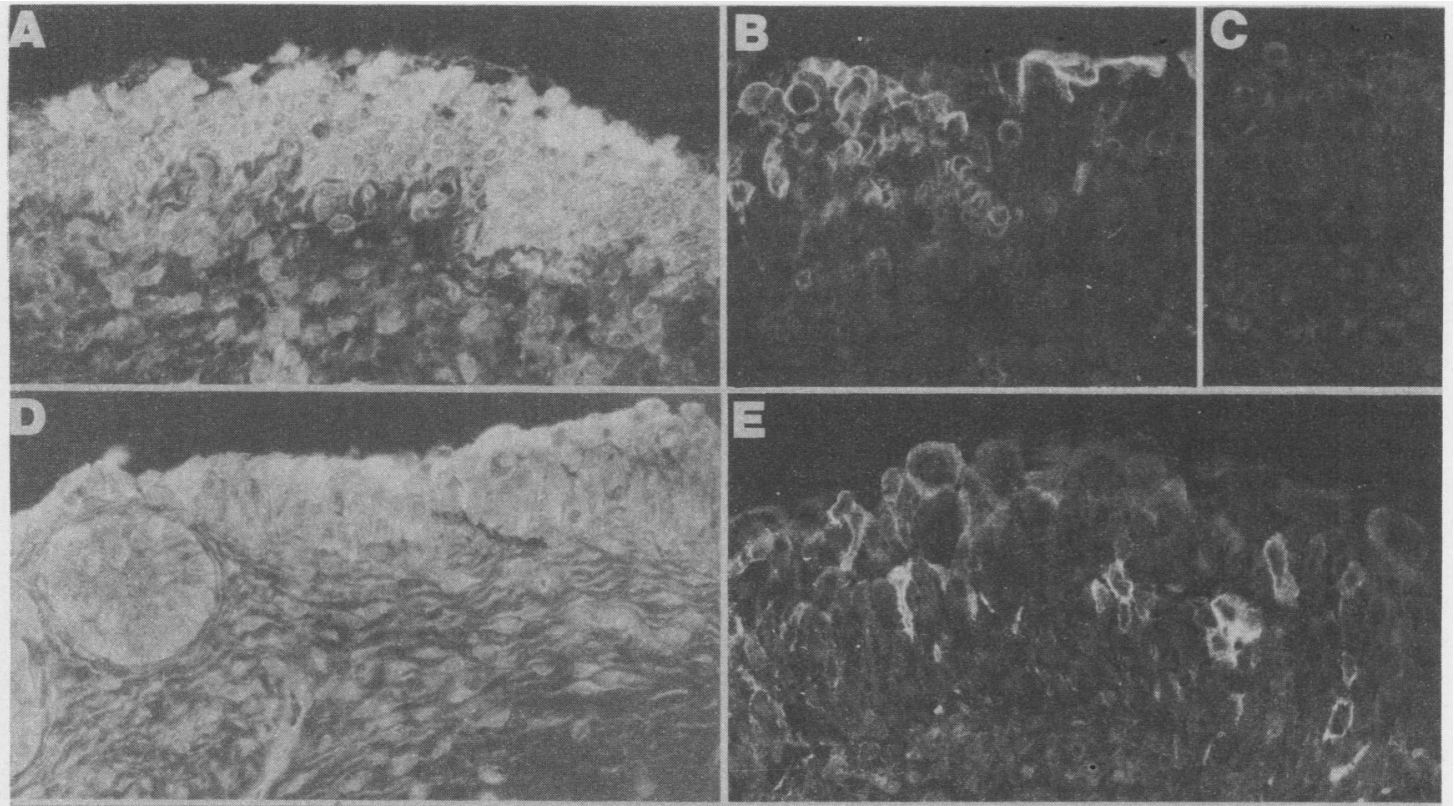

(c)

Fig. 2 Immunofluorescence staining of the blood group $H$ antigen in cryostat sections $(A, D, F)$ and paraffin sections $(B, C$, $E, G)$ of non-neoplastic bladder epithelium from persons of blood group $O$. $(A-C)$ and $(D, E)$ are from cases Buc and Liv (secretors) and $(F, G)$ from case Bla (non-secretor). In the cryostat sections there is also immunofuorescence staining of the cells in the connective tissue underlying the epithelium. Magnification $\times 225$. 
case Lym (blood group A) whose tumour was devoid of blood group A immunofluorescence (using freshfrozen tissue) although the blood vessels retained this antigen (Fig. 4A and inset). This tumour showed some residual $\mathrm{H}$ antigen staining (Fig. 4B). The tumour was highly malignant and rapidly progressive (Table 1 ).

(b) Focal deletion of blood group antigens. In two patients Bon and $\mathrm{Pal}$ (blood group $\mathrm{O}$ ) the $\mathrm{H}$ antigen was preserved in some areas and deleted in others in both the cryostat and the paraffin-sections (Figs 5 and 6). Both of these patients had superficial (stage T1) recurrences during the follow-up period of three years and one year respectively.

(c) Reduction of the blood group antigens. In the cryostat sections of two patients (Par and Ste) immunofluorescence with the appropriate anti-blood group serum was above control throughout the sections. However, the overall intensity of fluorescence was diminished in case Par, and there was some regional variation in case Ste. Superficial (stage T1) recurrences of the tumour occurred in the former patient but not in the latter during one year of followup.

\section{Discussion}

These results clearly show that paraffin sections are unsuitable for the assessment of blood group antigens in bladder tissues. This is not surprising in view of the original observation of Szulman ${ }^{1}$ that a substantial proportion of the blood group antigens in transitional epithelium is in an alcohol soluble form (presumably associated with glycolipids), and the more recent

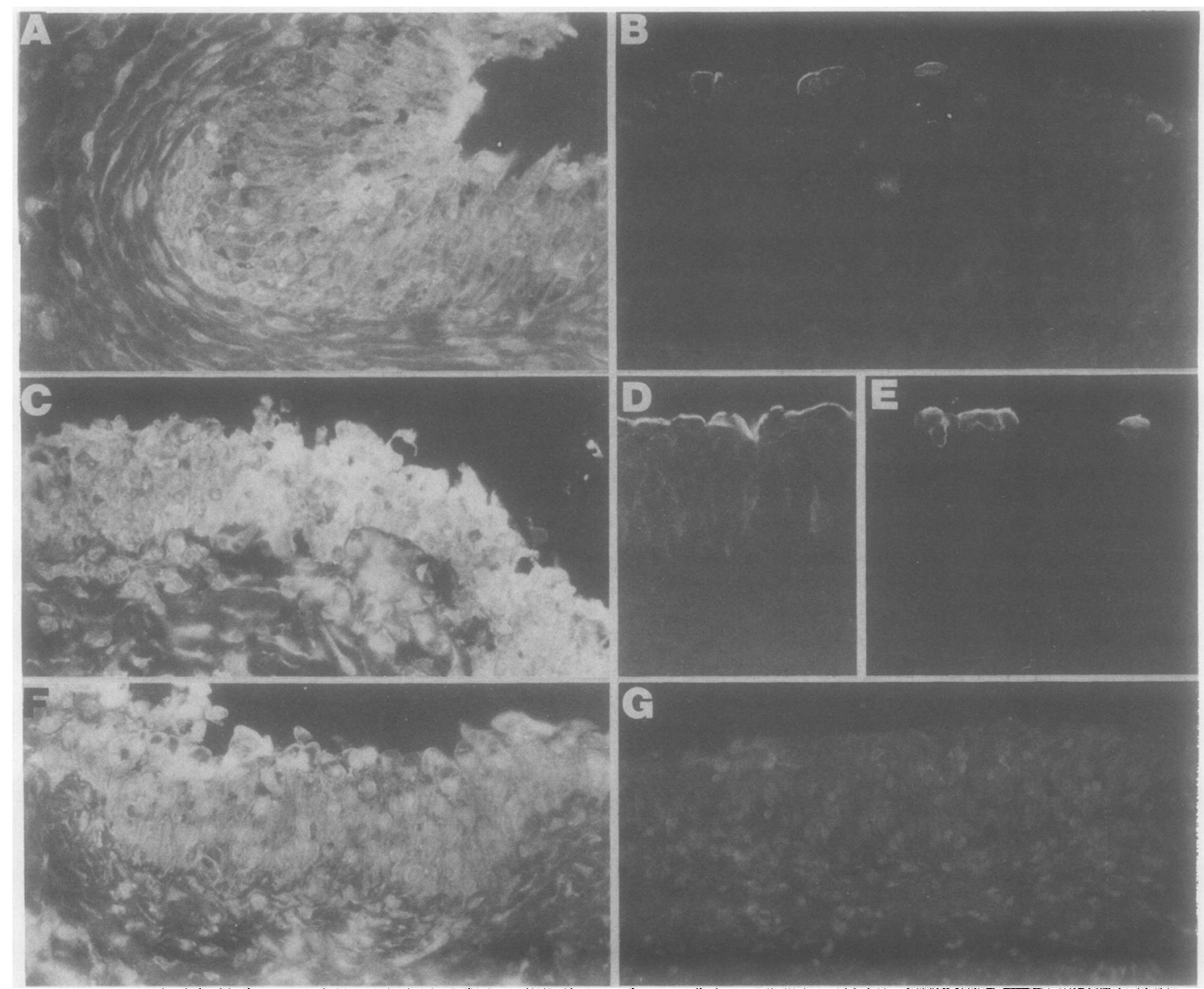

Fig. 3 Immunofluorescence staining of the blood group $H$ antigen in cryostat sections $(A, C, F)$ and paraj, tin sections $(B, D$, $E, G)$ of non-neoplastic bladder epithelium from persons of blood groups $A$ and $B$. $(A, B)$ are from case Wal (blood group $A$ secretor), (C-E) are from case Har (blood group B secretor) and ( $F, G)$ from case Dur (blood group B non-secretor). In the cryostat sections there is also immunofuorescence staining of cells in the connective tissue underlying the epithelium. Magnification $\times 225$. 

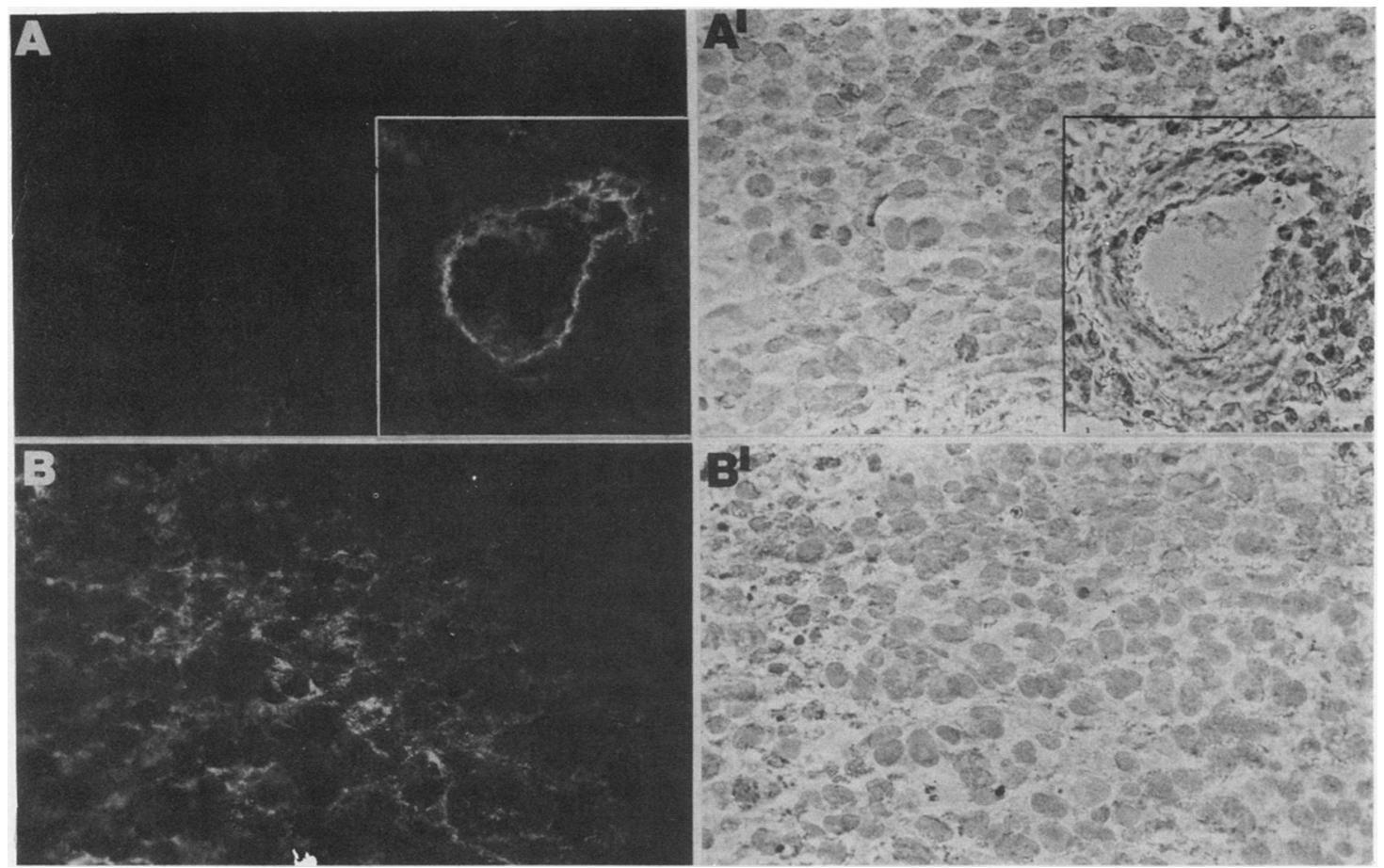

Fig. 4 Immunofluoresa nce $(A, B)$ and corresponding phase contrast micrographs $\left(A^{\prime} B^{\prime}\right)$ of cryostat sections of the bladder carcinoma of case Lym (blood group A secretor) showing total deletion of $A$ antigen from the tumour $(A)$ but preservation of this antigen in endothelium (inset) and partial deletion of the $H$ antigen (B). Magnification $\times 225$.

observation of Limas and Lange ${ }^{12}$ that ethanol used in the dehydrating of tissues prior to paraffinembedding results in the removal of blood group antigens from the bladder mucosa. Also, in agreement with these authors, we found that $\mathrm{H}$ antigen reactivity is more affected than $A$ antigen by this procedure, and the reduction of blood group antigen reactivity in the bladder mucosa is more pronounced in non-secretors than secretors.

Most previous studies of blood group antigens in bladder tumours have been carried out using paraffin-embedded material. Our observations may account for reports from such studies that blood group antigens are deleted in a considerable proportion of non-invasive bladder tumours. ${ }^{4}$ Thus cryostat sections of fresh-frozen tissues or sections processed in the absence of glycolipid-extracting solvents must be used for the reliable assessment of these antigens in the bladder mucosa. This is in contrast to gastric tissues where the blood group antigens are well preserved in paraffin sections. ${ }^{2}$ Presumably there is a higher proportion of glycoproteins carrying the blood group antigens in the gastric mucosa and a higher proportion of blood group active glycolipids in the transitional epithelium of the bladder. Furthermore, the bladder epithelium differs from gastric mucosa in that the blood group antigens are expressed in non-secretors as well as secretors. These observations are also in agreement with those of Szulman. ${ }^{1}$

All five patients with bladder cancer included in this study showed some reduction or loss of the appropriate $\mathrm{A}$ or $\mathrm{H}$ antigens in cryostat sections of their tumours. The patient with total loss of $A$ antigen was the only case of aggressive carcinoma. Loss of blood group $\mathrm{A}$ and $\mathrm{H}$ antigens would be expected to expose antigens associated with their precursors such as the $I$ and $i$ antigens. ${ }^{25}$ Immunofluorescence staining of $i$ antigen was observed in occasional epithelial cells in non-neoplastic bladder mucosae and in occasional cells in bladder tumours. However, in contrast to gastric tumours, ${ }^{23}{ }^{24}$ loss of $\mathrm{A}$ and $\mathrm{H}$ antigens in the bladder tumours in this study was not accompanied by a marked increase in the expression of the I(Ma) antigen in the tumour cells (SJ Thorpe and T Feizi, unpublished observations 1982). Immunofluorescence of $i$ antigen was also seen in cells having the appearance of mononuclear inflammatory cells in both the neoplastic and non-neoplastic epithelium as well as the underlying stroma. I antigen 

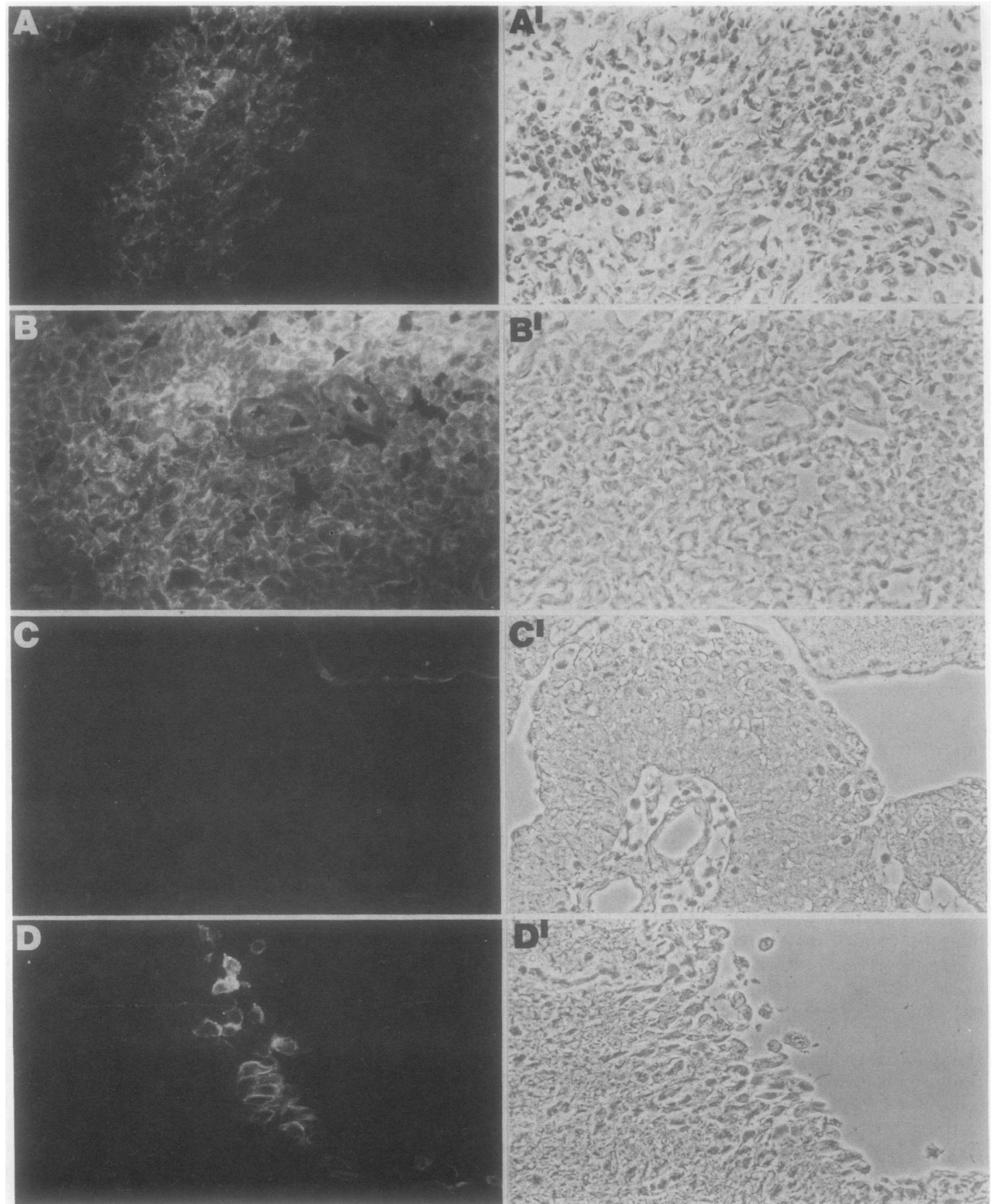

Fig. 5 Immunofluorescence $(A-D)$ and corresponding phase contrast $\left(A^{\prime}-D^{\prime}\right)$ micrographs of the bladder carcinoma of case Pal (blood group $O$ secretor) showing focal deletion of the $H$ antigen in cryostat sections $(A, B)$ and paraffin-embedded sections $(C, D)$. Magnification $\times 225$. 


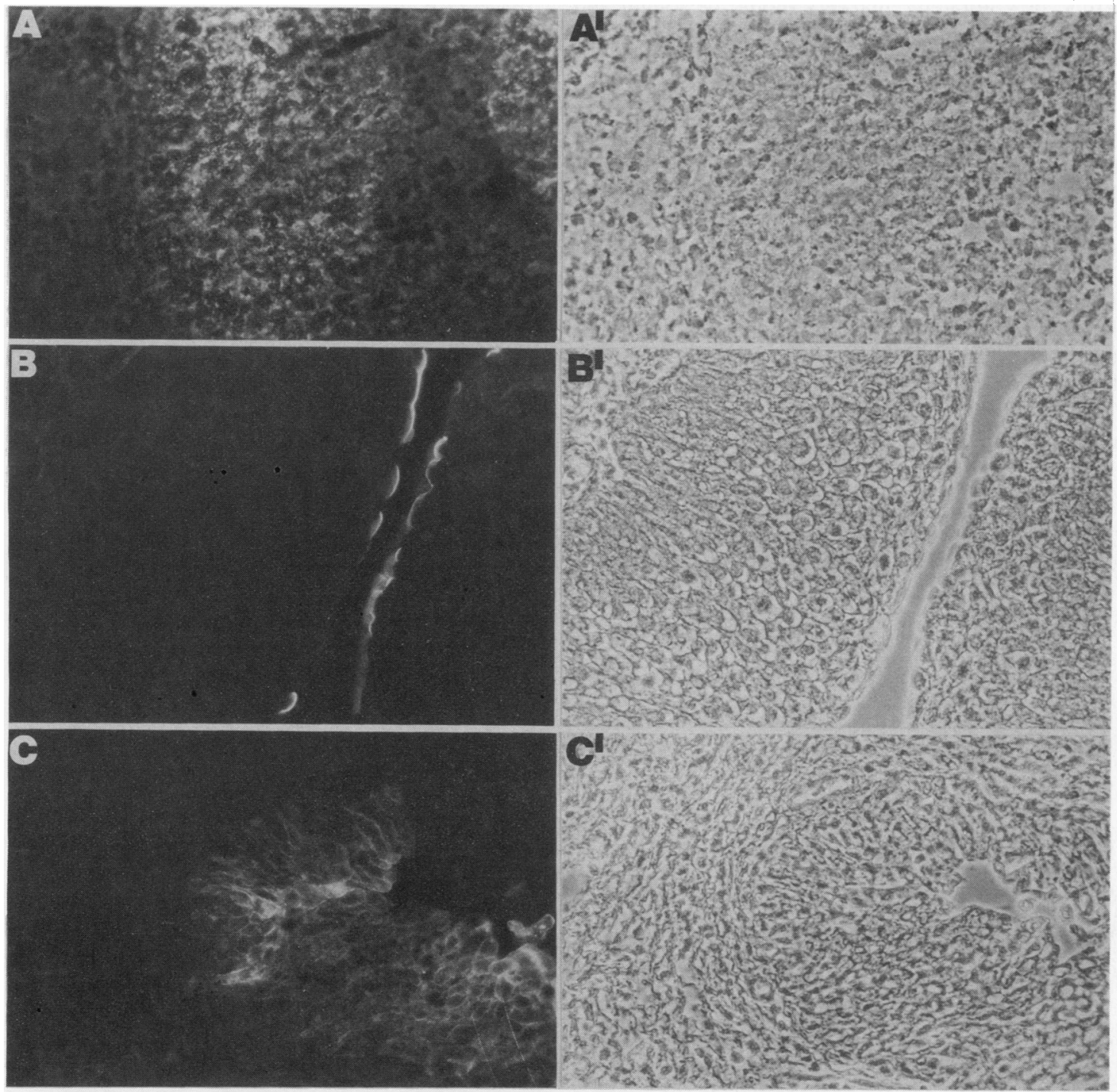

Fig. 6 Immunofluorescence $(A-C)$ and corresponding phase contrast micrographs $\left(A^{\prime}-C^{\prime}\right)$ of the bladder carcinoma of case Bon (blood group $O$ secretor) showing focal deletion of the $H$ antigen in cryostat $(A)$ and paraffin-embedded sections $(B, C)$. Magnification $\times 225$.

immunofluorescence was observed in occasional mononuclear cells and in endothelia. The peanut lectin receptor, another structure exposed as a result of incomplete biosynthesis of blood group related carbohydrate chains, ${ }^{26}$ was not studied in the present work. Using paraffin sections of bladder tumours, Coon et al have observed abnormal expression of this structure in a high proportion of invasive tumours. ${ }^{27}$ The usefulness of this marker warrants detailed investigation using cryostat sections of bladder tumours.
It will be of interest to establish whether the total deletion of blood group antigens at the time of presentation (as in case Lym in this study) or a change from partial to total deletion during follow-up, are characteristic of invasive tumours. However, this preliminary study of bladder tumours suggests that such criteria may not be sufficiently precise as prognosticators of malignant potential in view of the considerable differences in intensity of immunofluorescence among non-neoplastic epithelia, and the marked regional variation observed in non-invasive tumours. 
Thus, new antigenic markers should be sought and. these should ideally be markers which appear de-novo in the invasive or potentially invasive tumours but not in those of non-invasive type.

SJT is supported by the Cancer Research Campaign (UK). We are indebted to the Surgical Teams of $\mathbf{M r}$ PJ O'Boyle, Musgrove Park Hospital, Taunton, Somerset and Mr A Elton, Northwick Park Hospital, Harrow for providing the tissues used in these studies. We are also grateful to Mr M Harris, Musgrove Park Hospital, Mr P Ward and Miss M Manek, Clinical Research Centre, for their help in the preparation of the tissues and Mrs Sally Schwarz for typing the manuscript.

\section{References}

' Szulman AE. Chemistry, distribution, and function of blood group substances. Ann Rev Med 1966;17:307-22.

${ }^{2}$ Kapadia A, Feizi T, Jewell D, Keeling J, Slavin G. Immunocytochemical studies of blood group $A, H, I$ and $i$ antigens in gastric mucosae of infants with normal gastric histology and of patients with gastric carcinoma and chronic benign peptic ulceration. $J$ Clin Pathol 1981;34:320-37.

${ }^{3}$ Feizi T. Blood group antigens and gastric cancer. Med Biol 1982; 60:7-11.

4 Stein BS, Kendall AR. Blood group antigens and bladder carcinoma: a perspective. Urology 1982;20:229-33.

5 Barnes R, Hadley H, Dick A, Johnston O, Dexter J. Changes in grade and stage of recurrent bladder tumors. J Urol 1977;118: 177-78.

- Coombs RRA, Bedford D, Rouillard LM. A and B blood-group antigens on human epidermal cells demonstrated by mixed agglutination. Lancet 1956;1:461-3.

7 Catalona WJ. Practical utility of specific red cell adherence test in bladder cancer. Urology 1981;18:113-7.

${ }^{8}$ Bishop MC. Blood group antigens and bladder cancer. Br Med J 1982;284:1426-7.

9 Kay HEM, Wallace DM. A and B antigens of tumors arising from urinary epithelium. J Natl Cancer Inst 1961;26:1349-65.

${ }^{10}$ Fujita J, Matsumoto K, Kishi K, Ishiyama I. Synthesis of ABH blood group substances in bladder tumours. Br J Urol 1981;53: 448-52.

"Limas C, Lange P. Altered reactivity for A, B, H antigens in transitional cell carcinomas of the urinary bladder. A study of the mechanisms involved. Cancer 1980;46:1366-73.

12 Limas C, Lange P. A, B, H antigen detectability in normal and neoplastic urothelium. Influence of methodologic factors. Cancer 1982;49:2476-84.
13 Ramsey EW. Specific red cell adherence technique. Letter to the Editor. J Urol 1980;124:304.

14 Lange PH, Limas C. Tissue blood group antigen testing in transitional cell carcinoma of the bladder. Letter to the Editor. $J$ Urol 1980;124:304.

15 Coon JS, Weinstein RS. Detection of ABH tissue isoantigens by immunoperoxidase methods in normal and neoplastic urothelium. Comparison with the erythrocyte adherence method. Am J Clin Pathol 1981;76:163-71.

16 Cooper HS, D'Elia FL. Comparison between the methods of indirect immunofluorescence and specific red cell adherence in detecting ABH ISO-antigens in bladder carcinoma. Am J Clin Pathol 1982;77:548-54.

17 Coon JS, Weinstein RS. Variability in the expression of the $\mathrm{O}(\mathrm{H})$ antigen in human transitional epithelium. J Urol 1981;125: 301-6.

18 Sadoughi N, Mlsna J, Guinan P, Rubenstone A. Prognostic value of cell surface antigens using immunoperoxidase methods in bladder carcinoma. Urology 1982;20:143-6.

19 D'Elia FL, Cooper HS, Mulholland SG. ABH isoantigens in stage O papillary transitional cell carcinoma of the bladder: correlation with biological behavior. J Urol 1982;127:665-7.

${ }^{20}$ Mostofi FK. In: Histological typing of urinary bladder tumours. International Histological Classification of Tumours No 10. Geneva: World Health Organisation, 1973.

21 TMN classification of malignant tumours. 3rd ed Union Internationale contre le Cancer. Geneva, 1978.

${ }^{22}$ Kapadia A, Feizi T, Evans MJ. Changes in the expression and $\frac{C}{\mathscr{S}}$ polarization of blood group I and $\mathrm{i}$ antigens in post-implantation embryos and teratocarcinomas of mouse associated with cell differentiation. Exp Cell Res 1981;131:185-95.

23 Johnson GD, de C Nogueira Araujo GM. A simple method of reducing the fading of immunofluorescence during microscopy. J Immunol Methods 1981;43:349-50.

${ }^{24}$ Picard J, Waldron-Edward D, Feizi T. Changes in the expression of the blood group A, B, H, Le and Leb antigens and the blood group precursor associated $\mathrm{I}(\mathrm{Ma})$ antigen in glycoprotein-rich extracts of gastric carcinomas. J Clin Lab Immunol 1978;1: 119-28.

${ }^{25}$ Feizi $T$. The blood group Ii system: a carbohydrate antigen system defined by naturally monoclonal or oligoclonal autoantibodies of man. Immunol Commun 1981;10:127-56.

${ }^{26}$ Watkins WM. Biochemistry and genetics of the ABO, Lewis and $\mathrm{P}$ blood group systems. In: Harris $\mathrm{H}$, Hirschhorn $\mathrm{K}$, eds. Advances in human genetics. Vol 10. Plenum Publishing Co, $1980 ; 1-136$ \& 379-85.

${ }^{27}$ Coon JS, Weinstein RS, Summers JL. Blood group precursor $\mathrm{T}$-antigen expression in human urinary bladder carcinoma. $\mathrm{Am}$ J Clin Pathol 1982;77:692-9.

Requests for reprints to $\mathrm{Dr}$ Ten Feizi, Division of Communicable Diseases, Clinical Research Centre, Watford Road, Harrow, Middlesex HA1 3UJ, England. 